\title{
TRAVEL MEDICINE PRACTICE, EDUCATION AND RESEARCH IN BRAZIL - CURRENT STATE AND FUTURE PERSPECTIVES
}

\author{
Fernando Cardoso Oliveira*, Afonso Schultz de Souza**, Gerard Flaherty*** \\ Corresponding author: Dr. Gerard Flaherty. E-mail: gerard.flaherty@nuigalway.ie. \\ * Universidade Federal de Roraima, Boa Vista, Brasil. School of Medicine, National University of Ireland, Galway, Ireland. \\ ** Centro Universitário de Caratinga, Caratinga, Brasil. School of Medicine, National University of Ireland, Galway, Ireland. \\ *** School of Medicine, National University of Ireland, Galway, Ireland. International Medical University, Kuala Lumpur, \\ Malaysia.
}

\begin{abstract}
Objective: Travel medicine services and training are well established in the British Isles, but the situation in Brazil has not been extensively described. Methodology: We conducted a review of literature related to travel to travel medicine services and training in Brazil. Results: Specialised travel medicine clinics catering for departing travellers and ill returnees exist in the large Brazilian urban centres of Rio de Janeiro and São Paulo. Travel medicine educational events have been hosted by various institutions. Conclusion: The approach to travel medicine in the British Isles, with its focus on education and training, continuing professional development, and standards of practice, may reasonably be adopted in Brazil.
\end{abstract}

Keywords: Travel medicine; Practice; Education.

International travel from developed countries has increased rapidly in recent decades. The World Tourist Organization estimates that international tourist arrivals will reach 1.8 billion by 2030.(1) International tourist arrivals in the emerging economy destinations of Latin America, Asia, and Africa will grow twice as rapidly as those of developed economy destinations. Leisure is the most common reason for traveling overseas from the British Isles. Other reasons for travel include business trips, international sports activities, medical tourism, and humanitarian aid-work. Accidental injury is the commonest cause of travel-related death in younger age groups, 
while cardiovascular disease accounts for most of the illness occurring in older travelers. Vaccine-preventable diseases cause a relatively minor proportion of travel-related mortality but are responsible for significant morbidity.

The travel health-care provider requires knowledge of the epidemiology, recognition and prevention of travel-related infectious diseases, including tropical infectious diseases; the indications, contraindications and administration of travel vaccinations; the prevention and management of non-infectious travel health risks including those which may affect the traveller with preexisting medical conditions; and the identification of disease in returned travellers. The quality of pre-travel health-care depends on conducting a comprehensive and individualized risk assessment of the proposed travel itinerary taking account of the traveler's medical history, concurrent medications, allergies and immunization history (Figure 1). Consideration should be given to seasonality, mode of travel, planned activities, type of accommodation, and duration of travel. Preventive advice is tailored to the specific needs of the individual traveler but generally includes a discussion of the nature of vaccine-preventable travel-associated illness, prevention and self-treatment of travelers' diarrhea, and the prevention of malaria through mosquito bite avoidance measures and prescription of malaria chemoprophylaxis. ${ }^{(2)}$

Attention is given to personal safety and security precautions, the risks of sex tourism and the avoidance of sexually transmitted infections. Environmental illness, including heat and coldrelated injury, high-altitude illness, barotrauma associated with scuba-diving, and drowning risks associated with rip currents and jellyfish envenomation, must also be addressed. For some travellers, advice on minimizing jet lag, travelrelated deep vein thrombosis and motion sickness will also be indicated. Most pre-travel consultations will include the provision of detailed verbal information on the avoidance and management of potentially fatal rabies exposure.

Figure 1 - Essential elements of a Travel Medicine Service

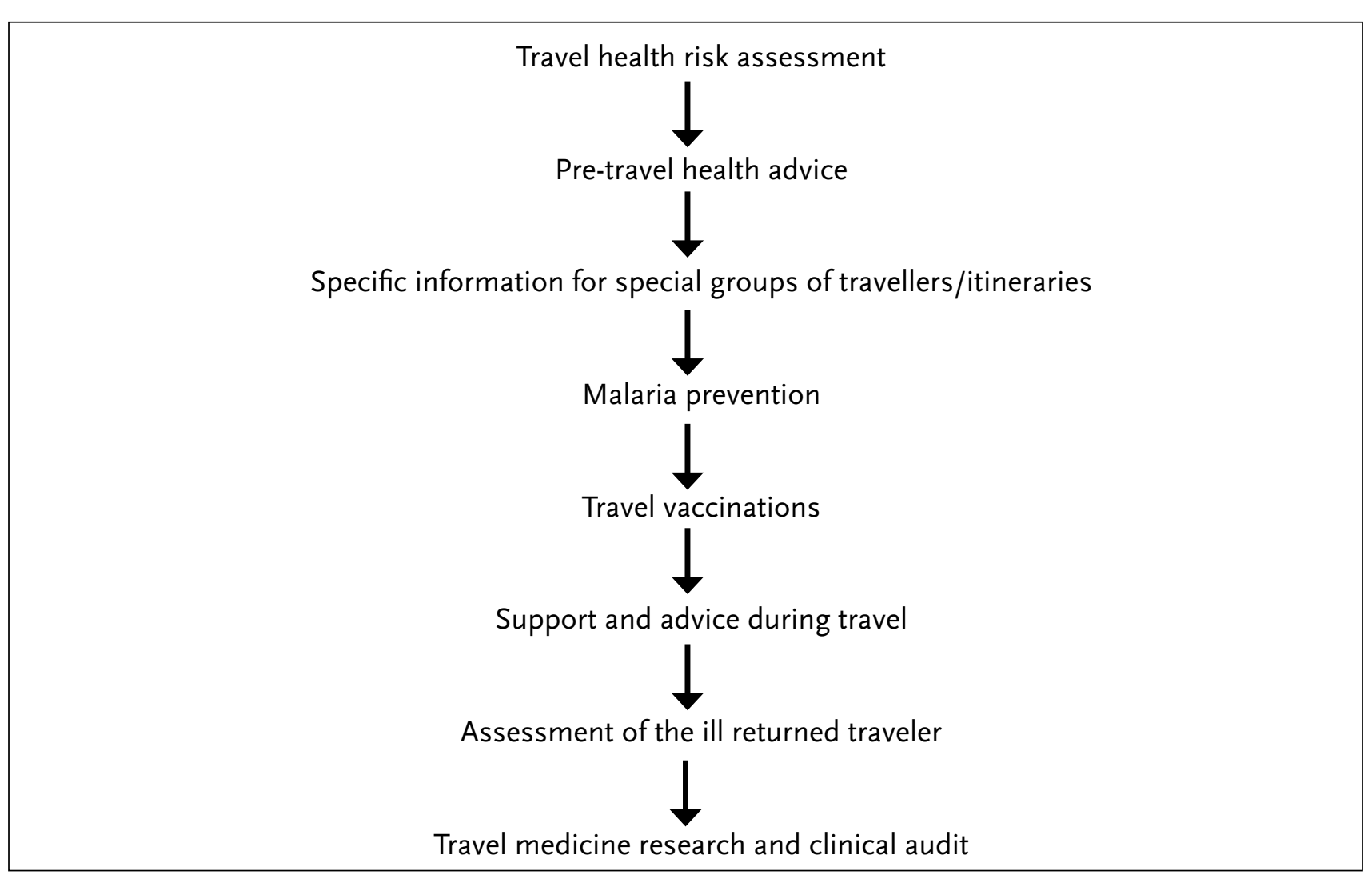


Some travelers will be advised to bring travel medical kits when traveling for prolonged periods in resource-poor settings. Travel health and medical evacuation insurance will be recommended to all travelers and specific guidance provided on how to access competent medical care overseas. The International Association for Medical Assistance to Travellers provides an excellent service to travel health professionals giving such advice. Some travel medicine providers may provide emergency contact information in the event of a medical emergency occurring overseas. Special groups of travelers will benefit from highly specialised advice derived from a detailed knowledge, both of the traveler's pre-existing medical condition and the effects of travel thereon. Such groups include the pregnant and breastfeeding traveler, the elderly traveler, the traveler with diabetes mellitus, families traveling with children, the immunocompromised traveler, and the disabled traveler. ${ }^{(3)}$

A relatively new phenomenon in travel medicine is that of medical tourism, whereby patients travel from developed to developing countries to receive medical care, including surgery and stem cell therapy, ${ }^{(4)}$ before returning to theirhomeland. In some cases, the travel medicine specialist will accompany the travelers, for example as team physician, healthcare worker accompanying a pilgrimage group or working for a non-governmental organization, or expedition doctor. Considerable knowledge of the health-care capacity and limitations of the host country is required in such cases. A planned posttravel assessment may be conducted in selected travelers, for example in aid workers or expatriates. The non-specialist travel medicine practitioner will be required to assess returned travellers and refer appropriately to infectious diseases experts as well as alerting public health officials where a suspected disease outbreak may be imminent. Psychological debriefing will be required for some returned travellers, including those travellers who have had to be repatriated owing to psychiatric reasons.

Travelers are also recognised as the means by which many new and emerging infectious diseases circumnavigate the globe. The introduction of novel pathogens may have both profound consequences for the health systems of receiving countries and detrimental long term economic effects. Examples from the last 20 years include HIV/AIDS, the spread of multi-drug resistant bacteria, and the recent outbreaks of Ebola viral disease in West Africa. In the last decade we have witnessed significant public health problems associated with travellers who imported SARS and, more recently, $\mathrm{H}_{1} \mathrm{~N}_{1}$ influenza and MERS-CoV viral infections.

In the British Isles, medical practitioners who practise travel medicine are drawn from a diverse range of professional backgrounds, including General Practitioners, Consultant Physicians specialising in Infectious Diseases or Tropical Medicine, Consultants in Public Health, and specialists in Occupational Medicine. Nurse Practitioners have equally varied backgrounds, and the Royal College of Nursing in the United Kingdom has published standards for practice in travel health. (5) In 2012 the Faculty of Travel Medicine at the Royal College of Physicians and Surgeons of Glasgow in the UK published its standards for the practice of travel medicine in the British Isles. ${ }^{(6)}$

The Diploma in Travel Medicine offered by the Royal College of Physicians and Surgeons of Glasgow was the first academic training programme leading to a recognised qualification in travel medicine. Entry to the Membership of the Faculty of Travel Medicine examination occurs through the Diploma in Travel Medicine examination or the International Society of Travel Medicine Body of Knowledge Certificate examination (Table 1). Elsewhere in the UK, both the London and Liverpool Schools of Tropical Medicine and Hygiene offer Diploma and Masters courses in tropical medicine.

Within the United Kingdom, authoritative websites dealing with travel health issues include those administered by the National Travel Health Network and Centre of the Department of Health, and Travax administered by Health Protection Scotland. The Foreign and Commonwealth Office gives guidance with respect to wider travel-related issues that impact on health such as personal security, country-specific information on travel risks, and consular advice. The British Global and Travel Health Association aims to promote a 
multi-disciplinary approach to travel health for the various disciplines involved in promoting the health of travelers by providing a forum for discussion, information exchange and education, as well as stimulating research on travel health issues. The Travel Medicine Society of Ireland has a similar role in the Republic of Ireland.

Table 1 - Body of Knowledge of the International Society of Travel Medicine

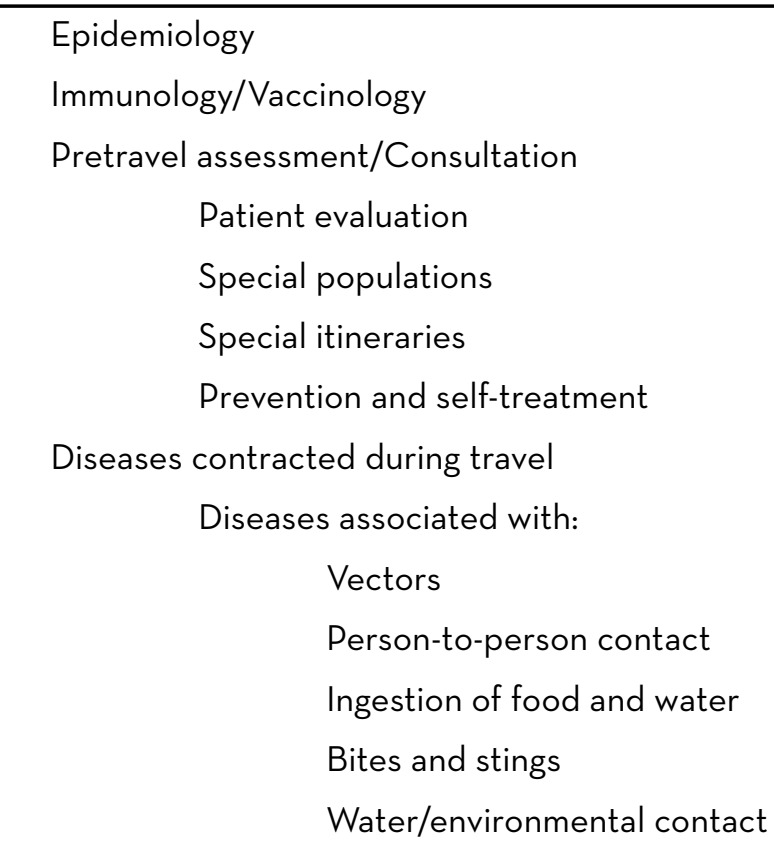

Other clinical conditions associated with travel

Occurring during or immediately following travel

Associated with environmental factors

Threats to personal security

Psychological and psycho-social issues

Post-travel assessment

Screening

Triage

Diagnosis

Management

Administrative and general travel medicine issues

Medical care abroad

Travel clinic management

Travel medicine information/resources

Adapted from: www.istm.org/bodyofknowledge

Travel medicine has only recently been established as a scientific discipline in Latin America. ${ }^{(7)}$ While travel medicine practice in Brazil began in 1997, there are few reports in the literature on travel health issues affecting outward Brazilian travellers. Significant attention has been given to the preparation of inward visitors to Brazil attending major international sporting events. ${ }^{\left({ }^{8}\right)}$ The purpose 
of the current study was to explore the origins and development of travel medicine practice in Brazil, to compare travel medicine in Brazil with that in the British Isles, and to anticipate the future potential for travel medicine delivery, education and research in this large Latin American nation.

Original and review articles published in English and Portuguese in the past 10 years and which related to travel medicine in Brazil were accessed in the literature databases PubMed and SciELO, using the keywords "travel medicine in Brazil, medicina de viagem, saúde de viajante, and traveler health in Brazil". Article reference lists were searched in order to yield other relevant publications. Websites relevant to travel medicine practice in Brazil were also studied. A total of 74 relevant articles were retrieved, 14 of which related directly to travel medicine or travel health.

According to the Brazilian Ministry of Tourism, the number of travelers from Brazil, both domestic and international, increased from 43 million to 50 million between 2007 and 2010.9) Approximately $15 \%$ of Brazilian travelers engage in international travel. Despite this, few reports exist regarding the health problems occurring in Brazilian travelers. One report described a 13.4\% incidence of travelers' diarrhea among travelers from the Northeastern region of Brazil. ${ }^{(10)}$ Faculty members of a large Brazilian university, travelling mostly for business purposes, had a self-reported incidence of travelrelated health problems of $13.6 \%$. ${ }^{(1)}$ Most such health problems related to the occurrence of respiratory tract infections. There was a low awareness of travel health risks, and $30 \%$ of the respondents travelled without health insurance protection. The authors advocated the implementation of health advice programs which would raise faculty awareness of the health risks associated with travel.

The first documented travel medicine service developed in Brazil was the Cives Information Center on Health for Travelers (http://www.cives. ufrj.br/), which was established in 1997 at the Faculty of Medicine of the Federal University of Rio de Janeiro. ${ }^{(12)}$ Additional travel medicine services arose at the Emílio Ribas Infectious Diseases Institute in São Paulo, and at the Travelers' Clinic of Hospital das Clínicas, at the University of São Paulo School of Medicine. Lo and colleagues at the Travelers' Clinic of Hospital das Clínicas published a profile of travellers attending their clinic for pretravel medical advice. ${ }^{(13)}$ The median age of travellers was 33.5 years, and the majority $(51 \%)$ traveled for business purposes. The most frequently visited destinations were Africa (47\%), Asia (31.7\%), and South America (21.4\%). The travel vaccinations which were administered most frequently were typhoid, diphtheria-tetanus, hepatitis A, hepatitis B, and yellow fever.

The 2001 Brazilian Infectious Diseases Congress in Rio de Janeiro and the 2002 Congress of the Brazilian Society of Tropical Medicine both hosted round-table discussions on travel medicine in Brazil. A symposium devoted to travel medicine took place at the Emílio Ribas Infectious Diseases Institute in São Paulo in 2002. The First Conference on Travel Medicine and the inaugural Symposium of the Brazilian Society of Travel Medicine were held in 2008. Rio de Janeiro attracted the Third Latin American Congress of Travel Medicine in 2012. Matos and Barcellos concluded from a literature review of 41 travel health-related articles that a need existed to direct health care policies at tourists, which would include a surveillance and notification system for tourists. ${ }^{(14)}$

In 2010, new travel medicine clinics appeared at the University of São Paulo at Ribeirão Preto and the University Federal de São Paulo, both of which offer pre-travel health consultations and diagnostic services for returned travellers. Chaves and colleagues highlight examples of disease outbreaks affecting travellers within Brazil, including outbreaks of malaria, Chagas disease, yellow fever, and influenza $A\left(\mathrm{H}_{1} \mathrm{~N}_{1}\right) .{ }^{(15)}$ The same author reported two cases of imported Chikungunya virus infection in Brazilian travelers returning from Indonesia and India. ${ }^{(16)}$ The specialist travel medicine clinics in São Paulo also provide continuing education in travel medicine and have contributed to the discussions regarding the regulation of travel medicine services throughout Brazil. Table 2 summarises the organizations involved in travel medicine education and training in the British Isles and Brazil. 
Table 2 - Agencies Delivering Travel Medicine Education and Training in the British Isles and Brazil

\begin{tabular}{l|l}
\hline \multicolumn{1}{c|}{ BRITISH ISLES* } & \multicolumn{1}{c}{ BRAZIL } \\
\hline $\begin{array}{l}\text { Faculty of Travel Medicine } \\
\text { British Global and Travel Health Association }\end{array}$ & $\begin{array}{l}\text { Latin American Society of Travel Medicine } \\
\text { Sociedade Brasileira de Medicina Tropical } \\
\text { Travel Medicine Society of Ireland }\end{array}$ \\
$\begin{array}{l}\text { National Travel Health Network and Centre } \\
\text { Health Protection Scotland }\end{array}$ & $\begin{array}{l}\text { Emílio Ribas Infectious Diseases Institute } \\
\text { Royal College of Nursing } \\
\text { Foreign and Commonwealth Office }\end{array}$ \\
\hline
\end{tabular}

*The designation "British Isles" encompasses the islands of Great Britain, Ireland, and over 6000 smaller isles.

In an editorial in 2003, it was argued that travel medicine should be incorporated into the work of the infectious disease specialist in Brazil. ${ }^{(2)}$ Nurses practising in Brazil are already involved in the administration of yellow fever vaccine in accordance with International Health Regulations of the World Health Organization. An expanded role for nurses in the emerging field of travel health, similar to that observed in the British Isles, has been proposed. ${ }^{(17)}$

The standards of medical care given to travellers, before, during and after travel should be as high as those practised in other branches of medicine and surgery. Internationally accepted standards of best practice, already in existence in the British Isles, should be adopted in Brazil and formal accredited training should become mandatory for all health-care professionals who provide medical advice to travellers. Assurance of the competence of travel medicine providers should be subject to national regulation by a competent authority. The traveling public should also be educated to recognise and minimise the health risks of travel. In the case of a large country such as Brazil, this includes both domestic and international travelers. Brazil has the potential to become one of the global leaders in travel medicine practice, education and research.

\section{ACKNOWLEDGEMENTS}

The authors wish to acknowledge the support provided by Coordenação de Aperfeiçoamento de Pessoal de Nível Superior (CAPES) to two of the authors (FCO and ASS), who received unrestricted educational scholarships to study at the National University of Ireland, Galway as part of the Science Without Borders program.

of interest.

\section{REFERENCES}

1. World Tourism Organization. Tourism towards 2030. Global overview. Madrid; 2011.

2. Hill DR, Ericsson CD, Pearson RD, Keystone JS, Freedman DO, Kozarsky PE, et al. The practice of travel medicine: guidelines by the infectious diseases society of America. IDSA Guidelines 2006;43:1499-1539.

3. Ryan ET, Wilson ME, Kain KC. Illness after international travel. New England Journal of Medicine 2002;347(7):505-516.

4. Connolly R, O'Brien T, Flaherty G. Stem cell tourism - A web-based analysis of clinical services available to international travellers. Travel Med Infect Dis 2014;12(6):695-701.

5. Royal College of Nursing. Travel health nursing: career and competence development. RCN guidance. London: RCN; $2 \mathrm{Ol} 2$. 
6. Chiodini JH, Anderson E, Driver C,

Field VK, Flaherty GT, Grieve AM, et al.

Recommendations for the practice of travel medicine. Travel Med Infect Dis 2012; 1O(3):109128.

7. Rodriguez-Morales AJ, Zuckerman JN. Extending across continents: Travel medicine and Latin America. Travel Med Infect Dis 2012; $1 \mathrm{O}(2): 55-56$.

8. Gallego V, Berberian G, Lloveras S, Verbanaz S, Chaves TSS, Orduna T, Rodriguez-Morales AJ. The 2014 FIFA World Cup: Communicable disease risks and advice for visitors to Brazil. A review from the Latin American Society for Travel Medicine (SLAMVI). Travel Med Infect Dis 2014;12:2O8-218.

9. Brazilian Ministry of Tourism. Statistics and indicators. Available from: http://www. dadosefatos.turismo.gov.br/dadosefatos/home. html (accessed December 8, 2014).

10. Cavalcanti A, Clemens SA, Von Sonnenburg F, Collard F, De Clercq N, Steffen R, et al. Traveler's diarrhea: epidemiology and impact on visitors to Fortaleza, Brazil. Rev Panam Salud Publica 2002;11:245-252.

11. Tome ACN, Canello TB, Luna EJA, Andrade Junior HF. Health problems awareness during travel among faculty members of a large university in Latin America. Preliminary report Rev Inst Med Trop 2013;55(1):55-59.

12. Igreja RP. Travel Medicine: a new field of work for the specialist in Infectious and Parasitic Diseases. Rev da Soc Bra de Med Trop 2003;36:539-540.

13. Lo SC, Mascheretti M, Chaves TSS, Lopes $\mathrm{MH}$. Vacinação dos viajantes: experiência do ambulatório dos viajantes do hospital das clínicas da faculdade de medicina da universidade de São Paulo. Rev Soc Bras Med Trop 2008;41:474-478.

14. Matos V, Barcellos C. Relações entre turismo e saúde: abordagens metodológicas e propostas de ação. Rev Panam Salud Publica 2010;28:128134.

15. Chaves TSS, Mascheretti M, Alves JR, Boulos M, Lopes MH. Travel medicine in the state of São Paulo, Brazil. Travel Med Infect Dis 2O12; 10:283-284.

16. Chaves TSS, Pellini ACG, Mascheretti M, Jahnel MT, Ribeiro AF, Rodrigues SG, et al. Travelers as sentinels for Chikungunya fever, Brazil. Emerg Infect Dis 2012;18(3):529-530.

17. Mallet AP, Dall'Agnol CM, Souza DB. Febre amarela: orientações de enfermagem à saúde dos viajantes em unidades básicas de saúde. Rev Gaúcha Enferm 2010;31(2):293-299. 